\title{
Student Reflections and Self- Assessments in Vocational Training Supported by a Mobile Learning Hub
}

\author{
Lisbeth Amhag, Malmo University, Malmö, Sweden
}

iD https://orcid.org/0000-0002-5263-3243

\begin{abstract}
The aim of this study is to contribute knowledge about what characterizes students' capabilities to reflect on and self-assess their professional development during four school based vocational training courses in distance higher education. What abilities and challenges appear in their written reflections and self-assessments with critical incidents about a situation, incident, or issue in their log journals, as well as in their discussions online. face-to-face (F2F), supported by a mobile learning hub (MLH) with both mobile and blended activities? Theoretically, the study is based on five major levels of reflection: reporting, responding, relating, reasoning and reconstructing. The results from a group of students' representative excerpts demonstrates the importance of letting student teachers have agency and mediate their subjective experiences during practical vocational training in progression, supported by mobile and blended tools, to understand and make sense of experience in relation to self, others, and contextual conditions for personal and professional learning.
\end{abstract}

\section{KEYWORDS}

Critical Incident, Distance Education, Evaluator Reflection, Mobile Artefact, Self-Assessment, Vocational Training

\section{INTRODUCTION}

The goal of academic and professional reflection, as well as of self-assessment, is to develop students' learning, enabling them to move between theory and practice and to achieve the highest level of reflection. In the context of higher education professions, frequently, reflection and self-assessment are used in both theoretical and practical courses (McIntosh, 2010). Reflection and self-assessment represent a kind of 'higher order thinking' to promote critical and creative 'meta-reflexivity' (Archer, 2010; Dickhut, 2003; Hatton \& Smith, 1995; Shaheen, 2010). Inquiry and dialogic argumentation are key dimensions in critical thinking and have been identified as pathways to argumentative competence (Kuhn, 2016). Reflection and self-assessment allow students to progress to argumentative competence and to act and think critically and professionally. Practical implementations of reflection and selfassessment include, in this study, written and online oral reflections with critical incidents about a 
situation, incident, or issue, which is essentially a procedure for gathering certain important facts concerning a clear situation (Flanagan, 1954). It is also important to make connections with theoretical readings and practical vocational training as a part of the teacher educational agenda, which should be modified and discussed to learn more about the specific situation, incident, or issue.

However, the common use of the concepts reflection and self-assessment is problematic, with little or no agreement on the meaning of these concepts among teachers or students. Often, it is taken for granted that students know how to think critically and write reflectively on their own. Moreover, the concepts are often unclear and used loosely to embrace a wide range of conceptions and strategies, because of a lack of teacher training in reflection and self-assessment methods (Bain, Ballantyne, Mills \& Lester, 2002; Hatton \& Smith, 1995; Ryan, 2013). Boud (1999) emphasized the importance of teaching students to act and think professionally, which involves the use of reflection and reflective practice as an informal learning-to-learn tool, as well as the use of self-assessment as a formal evaluation activity. The context of teaching and learning, both mobile and blended at distance, should enable students to translate knowledge from theory to educational and professional practice. According to Bain et al. (2002) students need to be able to connect vocational practise to theoretical knowledge in course literature, supported with a variety of educational and mobile tools, with sufficient time to use them and critically review and discuss the content to achieve educational goals. New media forms can easily be integrated into higher distance education, made possible by enhanced computer technologies, faster internet transmission, and different mobile devices (e.g. Amhag, 2016; 2017; Marin, Jääskelä, Häkkinen, Juntunen, Rasku-Puttonen \& Vesisenaho, 2016).

\subsection{The Study}

The aim of this study was to contribute knowledge about student teachers' capabilities to reflect on and self-assess their professional development during four school based vocational teacher training courses in one Vocational Teacher Education Program (VTEP) in Sweden, supported by a mobile learning hub (MLH). The MLH provides a mobile and blended prerequisite and activities across various dimensions, including the notion that students can learn anywhere and at any time, and easily switch learning contexts to another scenario, or a variety of scenarios. The MLH was accessible from the student teachers' laptops, tablets, and smartphones. Each semester had its own folder within the MLH (semester 1, semester 2, semester 3, and semester 4), where the student teachers could download different course documents, literature and instructions, as well as the students' own lessons plans with pictures and videos (see Figure 1). There were also folders in which they could post their written reflections and self-assessments after their vocational teacher training courses. The MLH also contained a link to an e-meeting system that hosted mobile online face-to-face (F2F) webinars, where students could discuss their written reflections, theoretical readings, and experiences with teaching practice, as well as participating in tutoring and scaffolding delivered by experienced teachers. Student teachers also had access, within the MLH, to a folder containing the recordings of webinar sessions. Links to the recordings of the mobile online F2F webinars were available afterwards for further critical review. Likewise, student teachers could use these recordings as input for their reflections and self-assessments in their log journals. The simple design of this MLH can easily be replicated in any learning platform.

\subsection{The Role of MLH}

The design of the MLH goes beyond simply adding new teaching, learning, and assessment strategies to an existing course. Instead, the design demonstrates how distance learning can be organized by an MLH to promote school based vocational training in higher education, both mobile and blended at distance. The MLH promotes collaboration and motivates reflection and self-assessment with critical incidents about a situation, incident, or issue encouraging students to find their own ways of learning and to act and think critically and professionally as an integral part of the vocational training courses. This mobile learning concept is called seamless learning. Seamless learning addresses the demand for 
Figure 1. The mobile learning hub (MLH) accessible from different digital devices

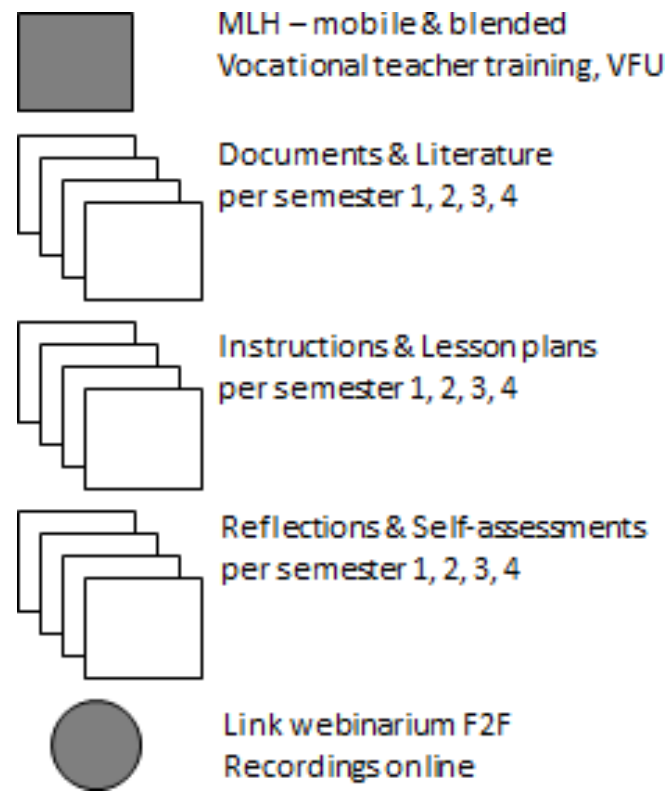

learning anytime and anywhere, extending formal/official learning time to include informal/casual learning time, and it includes opportunities for out-of-school learning through practice driven by the students' personal interests (Amhag, 2017; Chan, Roschelle, Hsi, Kinshuk, Sharples \& Brown, 2006).

Seamless learning represents a change from the traditional view of learning consisting of separate and distinct parts (e.g., in-class and out-of-class, academic at school and non-academic at practice, onand off-campus experiences), to a new view in which all aspects of education are bound together for lifelong learning (Kuh, 1996). Students can switch between on and off at their convenience, between formal and informal learning contexts, between reflecting and assessing, and between consuming before practice and creating in practice (e.g. Bach, Haynes \& Lewis Smith, 2007; Hwang, Lai \& Wang, 2015; Lan \& Lin, 2016; Wong \& Looi, 2011).

\section{PREVIOUS RESEARCH ON REFLECTION AND SELF-ASSESSMENT}

According to Sumsion and Fleet (1996), there is a fundamental tension between reflection and self- assessment. Reflection thrives on doubt and exploration, focusing on a lack of understanding, questioning, and probing discrepancies. Self-assessment, by contrast, requires certainty and involves a presentation of one's best work, emphasising what one knows, and reviewing the outcome. However, there are some possible interactions between reflection and self-assessment. Students can use their reflections as input for self-assessment after complementing assignments, teachers can foster reflection on the quality of others' work, and reflection can support transitioning into the next learning assignment.

Dochy, Segers and Sluijsmans (1999) describe six main topics of self-assessment: a) the influence of different abilities, b) the time effect, c) the accuracy, d) the effect of self-assessment, e) methods of self-assessment, and f) the content of self-assessment. These topics not only help students to make judgments about their own learning outcomes, but also allow them to consider the characteristics of competent work and learn how to apply these criteria to their own and others' work (De Wever, Schellens, Valcke \& Van Keer, 2006; Kostons, van Gog \& Paas, 2010). These self-assessment processes foster reflection on the quality of the students' reflections and the input of others after complementing 
the task, and to support next learning and development. Furthermore, the processes include creativity as 'higher order thinking skills' (Meyer, 2003; Richardson \& Ice, 2010; Schellens \& Valcke, 2005; Wegerif, 2007) to develop awareness of effective contributions and discussions online, and perceive the various qualities that contribute relevance. It is argued here that this type of creativity is a central characteristic of mobile and blended studies.

Reflection has been variously defined from different perspectives, such as critical theory or professional practice and disciplines (Bain et al., 2002). McIntosh (2010) stressed that, culturally, there has been an element of debate about reflection in theory and in practice. Reflection is seen as a 'good thing' to be encouraged in both theory and practice. Reflection is most clear in the relationship that exists between students and their teacher or teachers at school. These two ideas connect to students' need for pedagogical scaffolding to help them learn to reflect in deep, critical and transformative ways to produce supportable, progressive learning. First, a mutual understanding of what practice is needed; and second, the changed perspective of observing as a responsibility of the self, rather than of others. Superficial reflections, e.g. what is right and what is not right, have practically no impact on learning or future practice (McIntosh, 2010).

The models of Dewey and Schön are more comprehensive related to the study about student teachers' capabilities to reflect on and self-assess their professional development during practical vocational training. Dewey's (1938/1997) works provide a starting point for thinking about reflection and self-assessment because of the focus on the process of reflection, involving the active, persistent and careful consideration of any belief or supposed form of knowledge (Ashwin, Boud, Coate, Hallett et al., 2015). Dewey (1997) stressed that experience does not come directly from practical activities, but rather through interaction between reflection and activity, since theory and practice belong together. Similarly, experience does not come directly from reflections that lack anchoring in action. Through careful reflection on direct experiences, a self-assessment can be formulated, determining whether it is valuable to engage in a particular practice within a particular context. The capacity to reflect depends largely on how, and to what extent, the surroundings stimulate reflection.

Schön's (1987) work extended Dewey's ideas in analysing the actions of many different professional occupations. Central in reflection is the 'art' to deal with situations of uncertainly, instability, uniqueness, and value conflict (p. 50). One way to do this is through reflection-in-action, which hangs on the experience of surprise and the ability to think about doing something while doing it. This idea is captured in the common expressions 'thinking on your feet' and 'learning by doing,' which Dewey is often associated with (1938/1997, p. 54). Schön (1987) also described the process of reflection-on-action, or reflecting before and after teaching (e.g., teaching design, redesign, problem analysis, and identification of potential solutions to problems (Bain et al., 2002). According to Townsend (2010), Schön's 'reflective practicum' refers to a framework for learning by doing with the assistance of professionals as coaches. For example, a lesson in professional problem solving can generate new problems and confusions, which then become the material for reciprocal reflection between the student and the coach.

Other relevant perspectives on reflection come from practical research, where different levels of mental processing have been uncovered, progressing from transformative or intensive reflection through to dialogic reflection, then to assessing, and finally to critical reflection. In general, according to Hatton and Smith (1995, p. 34-35), reflective thinking addresses practical problems, permitting learners to experience doubt and perplexity before reaching possible solutions, to move towards "critical reflection". They are using Habermas' critique of reflection, divided into the following three levels: 1) Technical reflection, which is concerned with the competence and effectiveness of means to realise confident ends, and which is not open for criticism or modification; 2) Practical reflection, which is open for examination of both means and goals, the assumptions upon which these are based, and the actual outcome; 3) Critical reflection, which adds to the previous two types by making judgements about whether professional activity is equitable, a kind of ethical criterion. 
Existing research on reflectivity has used different analysis frameworks. One framework, which is used in this study, is the 5Rs, which Bain et al. (2002, p. 13) developed to enhance reflective writing and thinking in student teachers' journals. The purpose of the framework is to achieve two important purposes: a) to support student teachers' understandings of what is involved in serious reflection, and b) to enhance their ability to self-assess their writing. Bain et al. proposed five major levels of reflection: reporting, responding, relating, reasoning, and reconstructing, which are the 5Rs. Every level has distinct criteria to assist student teachers to develop their writing and reflective thinking.

Another way to analyse levels of reflection is described by Grossman (2009), drawing on a continuum based on Kuhn's (1989) and Kegan's (1994) research. The first level is content-based reflection, where experiences are considered against learning goals with structure, feedback, and opportunity to rewrite. This simple level needs some scaffolding that encourage students to focus on evidence. Second, metacognitive reflection is when "different strategies (thoughts) and in experiencing the excitement (feelings) of achieving a line or side" (p. 17), as to be "novice" in the teacher profession or "expert" in the vocational profession. At this level, learners need a lot of support and encouragement to develop this reflective capacity. Third, "self-authorship" reflection is when inner states become observed objects rather than lived subjects, facilitating consciousness "self-authorship." Attaining this level requires a capacity to separate thoughts and feelings from the sensory input that generates the process of reflection and to acknowledge that there is often more than one possible interpretation of experience. Fourth, transformative reflection, is a more advanced and deeper level of reflection, in which learners are empowered to become aware of thinking, perceiving, and acting, enabling them to accept increased social responsibility and become self-directed and less dependent on false assumptions. This level is applicable in courses and practical experiences where students come into contact with sufficiently strong conflicts that they have occasion to examine their assumptions. However, Giroux (2010) stressed that pedagogical practice does not transfer knowledge; instead it creates possibilities for an alternative reality in which the student can take an intellectual stance in dealing with critical issues and practices, and in which the student is empowered to initiate changes.

Clinchy (1996) defined knowing at two levels: 1) separate knowing, which involves distancing oneself through questioning another person's perspectives; and 2) connected knowing, which tries foremost to understand the other person's perspective. Enochsson (2017) showed that both separate and connected knowing are important to develop reflective thinking. At a group level, Enochsson found that discussions had similarities, but, at an individual level, learners needed different kinds of support to improve their reflective thinking. Ryan (2013) focused on the level of transformative reflection, observing that there were gaps in students' reflections. Specifically, they had difficulty connecting two key elements: 1) making sense of experience in relation to self, others, and contextual conditions; and 2) reimagining and/or planning future experience for personal and social benefit. Both elements are needed for true transformative reflection. This definition reflects the belief that reflection can operate at a number of levels and suggests that, to achieve the second element (reimagining), one must reach the higher, more abstract level of transformative reflection.

In summary, the studies reviewed here highlight the pedagogical balancing act of supporting different reflective levels, as in this study. Which is based on the 5Rs framework (Bain et al., 2002): reporting, responding, relating, reasoning and reconstructing, as a way to motivate focused reflection and self- assessment and help learners develop new ways of critical thinking and doing. Importantly, teacher educators must support every level of reflection, otherwise there will be specific, observable gaps in the reflections that students produce.

\subsection{Previous Research on Mobile Learning}

Mobile technologies are a research addition to higher distance education about their integration, what benefits are being observed, what challenges are being faced, and how these issues are being addressed. Pegrum, Oakley and Faulkner (2013) emphasise that mobile devices can support a variety of teaching methods, but it is important to plan how to use them. Important is the students' ability 
to use mobile devices in different contexts, such as in classrooms, field trips, or wherever learning situations can take place, to create opportunities for mobile and blended learning. In relation to the term seamless learning, the terms electronic learning (e-learning), mobile learning (m-learning), and ubiquitous learning (u-learning) are used to categorize the differences of learning (ibid, 2013).

Another perspective is how mobile devices can be conceived as mediators and cognitive tools that enhance the creation of seamless learning spaces (Amhag, 2016, 2017; Marin et al., 2016). The learning outcomes of Lan and Lin's (2016) study showed that a mobile group's text-based communication made significantly fewer errors and had more peer cooperation through the online support provided in their LMS, compared with a classroom group. Holistic seamless learning experiences and use of multiple technological devices are suggested by Wong and Looi (2011), such as different screen sizes, large shared displays, and large multi-touch screens. Another study by Wong (2013) showed that when students used smartphones to take photos in real-life contexts, and then posted them onto a wiki space for peer review, called a learner-generated context (LGC), seamless learning processes were crystallised in the interplay of physical settings and the mediation of mobile technology. In that way, new learning practices can bridge formal and informal aspects among students who negotiate in-school and out-of-school learning spaces, both mobile and blended (Wong, Chai, Aw \& King, 2015). The student participation significantly improved, but teachers must plan and stimulate online interactions, as well as create artefacts, such as teacher-recorded flipped classroom videos, instructions and examples of content.

\section{METHOD AND IMPLEMENTATION}

In the context of mobile and blended higher distance education, the goal of this qualitative case study, based on the 5Rs framework (Bain et al., 2002), was to contribute knowledge about student teachers' capabilities to reflect on and self-assess a critical incident about a situation, incident, or issue in their $\log$ journals, as well as in their discussions online F2F afterwards, supported by a mobile learning hub, MLH to provide broader conditions during their school based vocational teacher training courses. The following research questions are asked:

- What characterizes student teachers' reflective learning during vocational training?

- What opportunities and challenges are observed?

- Which critical incident in a situation, incident or issue are addressed and self-assessed?

The study involved a group of 51 vocational student teachers enrolled in a Vocational Teacher Education Program (VTEP) from January 2015 to January 2017. They were studying to become authorised vocational teachers for one of the upper secondary school vocational programs in Sweden, both mobile and blended at distance. All of them had been working for several years in their occupations. One third of them were working as informal vocational teachers (without teacher education); only a few had previously studied at a university. Each student had an e-portfolio in the learning platform. This study closely follows a group of six student teachers ( 2 women, 4 men), who were selected because they were using the same mobile online and blended offline activities supported through the MLH. Representative excerpts were selected from this group. Before the study, these six student teachers signed an agreement to participate and returned it via e-mail. At the end of the VTEP, they were again asked to provide their agreement to participate via e-mail.

\subsection{The Context of VTEP}

The Vocational Teacher Education Program (VTEP) in Sweden requires students to earn 90 credits, including six courses totaling 60 credits, both mobile and blended at distance in educational sciences, and 30 school-based credits in vocational teacher training at a partner school or within the students' own 
teaching position as informal teachers. Admission requires validated and relevant professional skills. As professionals, learners placed priority on their work; their academic distance studies presented a variety of fluctuating demands. All course content emphasizes strong links between vocational training and education. Semester 1 in VTEP focuses on social relations, conflict management, and educational leadership; semester 2 on syllabus, vocational didactics, and assessment; semester 3 on development, learning, and special education; and semester 4 on vocational didactic development.

The school-based courses in vocational teacher training have four learning goals. The first is linked to the development area of analysis and reflectivity. The second is linked to the development of subject areas of knowledge and didactic skills. The third is linked to the development of communicative and democratic leadership. The fourth and most complex goal requires students to do a self-assessment of their professional development, with a view to future vocational teaching. In this study, the focus is on the first goal, which encompasses reflection, and the fourth goal, which encompasses self-assessment.

\subsection{Data Collection}

The data collection is triangulated to confirm the results. First, the data consist of excerpts from written reflections and self-assessments of the six student teachers' professional development after each of four periods of school based vocational training over a 20-week period (spring and autumn, 2015, and spring and autumn, 2016). The written reflections and self-assessments include a critical incident about a situation, incident, or issue in their log journals, which were posted in the MLH. Second, the data also include three mobile online F2F webinars (3.5 hours) with oral discussions and reflections about a situation, incident, or issue, and the connection between theory and practice. The online F2F webinars were recorded and transcribed. Third, the data was complemented with a group interview online, conducted after the last period, in autumn, 2016. In the log journal with critical incidents, students were asked to answer the following questions, based on learning goals 1 and 4, and their answers were followed-up during the mobile online F2F webinars:

- Reflect on your teacher role and professional development based on a critical incident about a situation, incident, or issue;

- What needs do you have of additional theoretical and practical knowledge, based on conclusions of self-assessment?

- In what way can you further develop experience-based knowledge and professional skills?

\subsection{Data Analysis}

The study uses the 5Rs framework by Bain et al. (2002, p. 13) in the analysis of the student teachers' reflections and self-assessments with critical incidents about a situation, incident, or issue in their log journals, as well as during discussions mobile online F2F webinars. Analysis was based on the five major levels of reflectivity: reporting, responding, relating, reasoning, and reconstructing. Individual skills are ranked from these four reflection types. Level 1: the least developed with minimal descriptions. Level 2: adding broader descriptions to level 1. Level 3: adding sufficient details and own conclusions to level 1 and 2. Only type reconstruction has four levels by adding new understandings applied to a personal approach or theory of teaching to level 1, 2 and 3 (see Table 1). The five reflection types characterize the students' reflection capability by analysing these levels of abilities and challenges they demonstrate in their logbooks and by observing the mobile online webinars F2F what critical incident about a situation, incident, or issue are addressed and self-assessed. For each participant, the five levels of reflection are ranked according to the rubric in Table 1, and the results contain representative excerpts of the progressions. 
Table 1. The 5 Rs framework with criteria for each level (Bain, Ballantyne, Mills \& Lester, 2002, p. 13)

\begin{tabular}{|c|c|c|c|c|}
\hline 5Rs Framework & Level 1 & Level 2 & Level 3 & Level 4 \\
\hline $\begin{array}{l}\text { Reporting } \\
\text { Descriptive account of what } \\
\text { happened or of the situation, } \\
\text { incident, or issue. }\end{array}$ & $\begin{array}{l}\text { Minimal description } \\
\text { of the situation, } \\
\text { incident, or issue. }\end{array}$ & $\begin{array}{l}\text { Broad description } \\
\text { with limited } \\
\text { significant details. }\end{array}$ & $\begin{array}{l}\text { Sufficient details, } \\
\text { allowing learners } \\
\text { to draw their own } \\
\text { conclusions. }\end{array}$ & \\
\hline $\begin{array}{l}\text { Responding } \\
\text { Emotional or personal } \\
\text { response to the situation, } \\
\text { incident, or issue. }\end{array}$ & $\begin{array}{l}\text { Focuses on } \\
\text { significant aspects } \\
\text { with related feelings. }\end{array}$ & $\begin{array}{l}\text { Reasoned } \\
\text { judgement of a } \\
\text { situation, incident, } \\
\text { or issue. }\end{array}$ & $\begin{array}{l}\text { Adds to levels } 1 \text { and } \\
2 \text { by questioning or } \\
\text { identifying a problem. }\end{array}$ & \\
\hline $\begin{array}{l}\text { Relating } \\
\text { Relate or make a connection } \\
\text { between current personal or } \\
\text { theoretical understandings } \\
\text { of the situation, incident, or } \\
\text { issue. }\end{array}$ & $\begin{array}{l}\text { Own strength, } \\
\text { weakness, personal } \\
\text { learning, professional } \\
\text { matters, or future } \\
\text { practice. }\end{array}$ & $\begin{array}{l}\text { Adds to level } 1 \\
\text { a superficial or } \\
\text { limited discussion } \\
\text { of the connection } \\
\text { to theory. }\end{array}$ & $\begin{array}{l}\text { Adds to levels } 1 \text { and } \\
2 \text { expanded insight, } \\
\text { discussions, or } \\
\text { understandings of the } \\
\text { connection between } \\
\text { theory and practice. }\end{array}$ & \\
\hline $\begin{array}{l}\text { Reasoning } \\
\text { Highlight in detail or show } \\
\text { why the situation, incident, } \\
\text { or issue occurred with } \\
\text { exploration, questioning, or } \\
\text { explanation. }\end{array}$ & $\begin{array}{l}\text { At least one relevant } \\
\text { factor analysed in } \\
\text { detail with regard } \\
\text { to its importance, } \\
\text { impact, or questions } \\
\text { for future practice. }\end{array}$ & $\begin{array}{l}\text { Adds to level } \\
1 \text { alternative } \\
\text { explanations } \\
\text { and / or } \\
\text { interrelationships / } \\
\text { factors. }\end{array}$ & $\begin{array}{l}\text { Adds to levels } 1 \text { and } 2 \\
\text { insights from different } \\
\text { perspectives. }\end{array}$ & \\
\hline $\begin{array}{l}\text { Reconstruction } \\
\text { Drawing conclusions and } \\
\text { developing a future action } \\
\text { plan based upon a reasoned } \\
\text { understanding of the } \\
\text { situation, incident, or issue. }\end{array}$ & $\begin{array}{l}\text { The discussion leads } \\
\text { to a conclusion or } \\
\text { a plan for future } \\
\text { action. }\end{array}$ & $\begin{array}{l}\text { Adds to level } 1 \text { a } \\
\text { consideration of } \\
\text { the reason. }\end{array}$ & $\begin{array}{l}\text { Adds to levels } 1 \\
\text { and } 2 \text { the possible } \\
\text { impacts of different } \\
\text { circumstances. }\end{array}$ & $\begin{array}{l}\text { Adds to levels } \\
1-3 \text { new } \\
\text { understandings } \\
\text { applied to } \\
\text { a personal } \\
\text { approach or } \\
\text { theory of } \\
\text { teaching. }\end{array}$ \\
\hline
\end{tabular}

\section{FINDINGS AND ANALYSIS}

The following representative excerpts come from a representative group of six student teachers' written reflections and self-assessments with critical incidents about a situation, incident, or issue in their log journals, as well as during discussions online F2F from four school-based courses with vocational training in VTEP over a period of two years, supported through an MLH. The findings are oriented around the two learning goals of vocational training: 1. analysis and reflectivity of the student teachers' role and professional development in connection with the theoretical studies. 2 . self-assessment of their professional development with a view to future vocational teaching. The researchers analyse and characterize participants' progress toward these goals using the 5Rs framework and criteria (Bain et al., 2002) to ensure validity of observations. After the excerpts, the findings are summarized and analysed (Table 2).

In summary, we observe that, in excerpt 1 from semester 1 in school based vocational training; the student displays the most basic level of reflection, with reporting and relating aspects that reflect an initial emotional response and a superficial basis. The student progresses to the highest level of reflection at the end of semester 4, with reasoning and reconstructive aspects of reflection on different situations, both practically and theoretically. However, it is crucial that the student shows a clear progression, already evident in semester 2, with level 2 responding reflection about teaching design for pupils' learning outcomes, as well as reasoning reflection at level 3, with insights from different viewpoints. The student is presenting a critical incident with deeper insights and perspective, which can lead to higher levels of reflection (Archer, 2010). After semester 3, the 
Table 2. Student 1 is from treatment and care program and has worked as a nurse for many years

\begin{tabular}{l} 
From the Log Journal \\
\hline Critical incident semester 1 \\
I have read a lot about different theories and think it would be great if I can make the \\
theories my own, but I realize that it can take a long time until I feel them inside me. I \\
have been able to "feel them in the air" during my training and would like to practice that \\
way. This class of secondary school pupils, the teacher has no good relationships. The \\
class can be characterized as disharmonious. Five of the eight pupils have an immigrant \\
background and have very little knowledge of the Swedish language. Because of this \\
situation, the atmosphere in the class becomes more infected, it becomes difficult for the \\
teacher to handle the teaching. \\
Conclusions of self-assessment \\
That conflict which arises can be solved in different ways depending on what it is. My \\
claim is to listen to all without imparting any of my own values into the problem. I must \\
be there for the pupils.
\end{tabular}

Critical incident semester 2

My self-confidence has been balancing between succeeding and failing as a teacher, and it can only get better when I have got through various difficult trials. I have tried during this period to contribute to a joyful and efficient classroom together with the pupils in year 3. I have invested a lot of work in designing lesson plans according to the learning goals that go hand in hand with research on different teaching methods and learning.

\section{Conclusions of self-assessment}

I believe strongly that a teacher gains a great deal from:

1. Plan the next topic lesson with pupil-based topics, then they are responsible for their learning, which can stimulate motivation.

2. The pupils are tasked to be prepared from their own questions for the next lesson.

3. As the teacher better understands what the pupil can and wonder about, the opportunity is given to plan and preparing future lessons.

4. Always provide feedback with emphasis on progress made and provide suggestions for new goals.

\section{Critical incident semester 3}

During my teaching practice this period, I have experienced that teachers find that there is quite a lot involved in the teacher mission, and that it is difficult to know what to prioritize when resources are insufficient, while the pupil groups are increasingly different in knowledge and size. My view is also that there is much involved in the objectives, and that nobody really knows how much or what matters most.

\section{Conclusions of self-assessment}

I feel that I can describe and relate to theories of knowledge, learning, and development, as well as relate them to the national curriculum. As a teacher, I want to work on the basis of a scientific approach. I am used to working and teaching in a scientific way as a nurse. In course literature describes professional knowledge including a vocational language with associated vocational theoretical concepts, and that professional knowledge is based on scientific reasons of varying degrees.

\section{Critical incident semester 4}

As a student teacher, I experienced a gradual development during VTEP, but there has also been a rollercoaster of frustrations, reflections, and solutions about my own teaching, role, and mission as teacher. My theoretical abilities have been developed, but mostly in practice in the meetings with pupils, teachers, and parents. I have received many tools from my vocational teacher training that stimulate my career development in a positive direction.

\section{Conclusions of self-assessment}

I've thought a lot about the teacher's mission to promote pupils' knowledge, but also to educate them for the society. According to Vygotsky, pupils are learning and developing with others through their own choice in a socializing community (course literature). We live at a time when the school is characterized by economic demands on profitability, international knowledge measurements, and efficiency requirements. The teacher's mission is to promote the development of knowledge, but it is much more than that, and it is described in the literature as a dual mission (course literature).
Application of the 5 Rs Scale

In these sentences, the student is reporting (level 1) about different theories and wishes to make them her own. The description of the conflict between pupils exhibits less exploration or questioning; only referring to their immigrant background.

The further conclusion is relating (level 1) the situation to personal learning, and some future practice. However, there are no connections from theories or the teaching plan.

Here the student is responding (level 2) by judging the classroom as joyful and efficient and focusing on the pupils by designing teaching for pupils' learning outcomes. The further conclusion is reasoning (level 3) about what the student believes about teaching, with insights from different perspectives on pupil-based topics, as well as questioning for better understandings of pupils' learning. However, there is a lack of any theories or questioning on vocational didactics.

Here the student is relating (level 2) to the teaching objectives by drawing a superficial relationship between teaching resources and size of pupil groups and what matters most, but without any theoretical connection.

The further conclusion is relating (level 2) to the student's own feelings on scientific learning, with one limited connection to literature about scientific reasons of varying degrees.

Finally, the student is relating (level 3) to the theoretical and practical development as a rollercoaster between teaching, role, and mission as teacher, with expanded insight about different tools that stimulate the career in a positive way. The further conclusion is a reconstruction (level 4) with possible impacts of promoting pupils learning and socializing at a time with economic demands and international dimensions, applied to theory of teaching. 
reflections fall back to rather superficial, level 2 relating reflection, with incomplete and merely descriptive theoretical connections. Furthermore, the context of teaching and learning regarding special education was not taken into account for the ongoing translation of knowledge from theory to practice (Boud, 1999). In this excerpt, we observe the ability to connect practical and theoretical knowledge, as well as an understanding of the interconnection between the self and others in a social context and an ability to reason through dialogic reflexive deliberations (Bain et al., 2002; Hatton \& Smith, 1995; McIntosh, 2010) (Table 3).

In summary, excerpt 2 displays basic reflection on level 1 with relating, responding, and reporting aspects after all four semesters. The relating and responding levels show a kind of internal conversation in the reflective process, with some relationships based on personal and collegial interactions regarding pupils' learning and theoretical understandings in reading, but without any expanded insight on the discussions. In reasoning, which this student only used in semester 1, learners move from a largely personal response to an intellectually relevant reflection, as here about the importance of meeting the pupils at their knowledge level and engaging and motivating them. However, the student lacks rigorous analysis of the context or theoretical connection (Archer, 2010; Ryan, 2013). After the change of practice during semester 3, the student describes only limited perceptions about more focused pupils at a national program, without any practical comparison, contrast, or analysis of significant differences from the vocational introduction class. The essence of this excerpt is the importance of collegial learning and professional experiences in teaching, as well as how to document and plan lessons to increase goal achievement for the pupils (Table 4).

In summary, excerpt 3 demonstrates, after semester 1, the most basic level of reflection, with reporting and relating aspects, about the need of insights into different methods and theories to fully understand them and to develop collective and individual teaching. By the end of semester 4, the student has reached the highest level of reflection, with reasoning and reconstructive insights at levels 3 and 4. This is an example of metacognitive reflection, where the student connects thoughts to the use of different strategies, such as formative assessment and critical review of one's own practice (Grossman, 2009). This excerpt also shows the importance of help and support during the tripartite conversation between the teacher educator and the supervisor at the school, which can provide challenging encouragement to develop reflective capacity for further development as teacher.

\section{KEY RESULTS AND CONCLUSION}

The aim of this qualitative case study was to contribute knowledge about what characterizes student teachers' reflection capabilities during four school based vocational training courses in higher distance education, supported by a mobile learning hub, MLH. The research questions are: 1. What characterizes student teachers' reflective learning during vocational training? 2. What opportunities and challenges are observed? 3. Which critical incidents in a situation, incident or issue are addressed and self-assessed?

The data collection is triangulated by the student teachers' written log journals, oral discussions mobile online F2F, as well as a group interview online. The close study of a group of six students is, on one hand, the weaknesses of the study, because the results cannot be generalized. On the other hand, the results presented in the representative excerpts gives broad statements from specific log journals which situations, incidents, or issues are addressed and self-assessed, based on the 5Rs framework (Bain et al., 2002), with levels of reporting, responding, relating, reasoning, and reconstructing to understand the process of reflection (Dewey, 1938/1997).

The overall result answers the second research question by finding that it is important that students have the ability to be active agents who mediate and challenge their subjective experiences, e.g. feelings and descriptions of practical and theoretical knowledge and teaching practises (Archer, 2010). Likewise, the students objective circumstances, e.g. course and assessment requirements to act in certain ways during the school based vocational teacher training courses at a partner school 
Table 3. Student 2 is from a vehicles and transport program in vocational education and has worked as an informal vocational teacher for five years, after several years as a car mechanic

\begin{tabular}{|c|c|}
\hline From the Log Journal & Application of the 5Rs Scale \\
\hline $\begin{array}{l}\text { Critical incident semester } 1 \\
\text { I feel that I have had a rather long practice already, since I have worked at the } \\
\text { school for five years, first as a resource for three years, then with my own class. But } \\
\text { since I started VTEP, I've become more observant of things that happen based on } \\
\text { what we read and learned at the lectures. } \\
\text { Conclusions of self-assessment } \\
\text { It is important that we meet the pupils in their knowledge and not take for granted } \\
\text { that they can do certain things. I have also begun to think about how to better } \\
\text { motivate my pupils to be on time and be more involved in what is happening in the } \\
\text { classroom and at school. }\end{array}$ & $\begin{array}{l}\text { In these sentences, the student } \\
\text { is relating (level 1) between } \\
\text { personal learning at lessons and } \\
\text { theoretical understandings in } \\
\text { reading. The further conclusion } \\
\text { exhibits reasoning (level 1) about } \\
\text { the importance of meeting the } \\
\text { pupils at their level of knowledge } \\
\text { and better motivating them, but } \\
\text { without any theories. }\end{array}$ \\
\hline $\begin{array}{l}\text { Critical incident semester } 2 \\
\text { After each day, I and my colleagues discuss and analyse the day's lessons. I feel } \\
\text { I can better document and plan my teaching to increase goal achievement for } \\
\text { the pupils. I have also become more comfortable with the fact that my previous } \\
\text { professional experiences are very helpful in teaching. } \\
\text { Conclusions of self-assessment } \\
\text { My ability to meet the pupils in their knowledge and sense of mind has improved } \\
\text { when I feel me more engaged with the pupils. Then they listen and respect my } \\
\text { teaching in practice more. I have now extra understandings about documentation of } \\
\text { the pupils' knowledge, both in school and during their workplace-based learning. }\end{array}$ & $\begin{array}{l}\text { Here the student is relating (level } \\
\text { 1) to the collective study about } \\
\text { pupils' learning and professional } \\
\text { experiences in teaching. Likewise, } \\
\text { the further conclusion relates } \\
\text { information about the student's } \\
\text { own strength of engaging the } \\
\text { pupils' knowledge. However, } \\
\text { the text still lacks any theories } \\
\text { or questioning of vocational } \\
\text { didactics. }\end{array}$ \\
\hline $\begin{array}{l}\text { Critical incident semester } 3 \\
\text { During this semester I have practiced in a class in the National Vehicle Program. } \\
\text { It's always useful to change to a new group of pupils and get some experience- } \\
\text { based learning about how my colleagues work and plan their courses. The biggest } \\
\text { difference for me is that it is easier to plan for a more focused group, than in } \\
\text { vocational introduction. However, there are also pupils who have difficulty in } \\
\text { different subjects or are unmotivated, especially theoretically. } \\
\text { Conclusions of self-assessment } \\
\text { What I miss when I'm only in a class for a short period is how much easier it is to } \\
\text { teach pupils where I know them and have built mutual trust. During this semester, I } \\
\text { have understood how much I'm already working on special education for my pupils } \\
\text { in vocational introduction. }\end{array}$ & $\begin{array}{l}\text { Here the student is reporting } \\
\text { (level 1) the change of practice } \\
\text { leading to an insight about } \\
\text { teaching at a national vocational } \\
\text { program, where the pupils are } \\
\text { more focused, but also have some } \\
\text { difficulties. } \\
\text { The further conclusion is } \\
\text { responding (level 1) to the } \\
\text { importance of relationships with } \\
\text { pupils and their need for special } \\
\text { support. The text still lacks } \\
\text { theories. }\end{array}$ \\
\hline $\begin{array}{l}\text { Critical incident semester } 4 \\
\text { This last semester, I have been thinking a lot about how I can develop vocational } \\
\text { introduction for the pupils' workplace-based learning. The biggest problem I see is } \\
\text { that we have to fight for our pupils at school; despite the fact that the introduction } \\
\text { program is the biggest program at school, we are often set aside for the national } \\
\text { programs. } \\
\text { Conclusions of self-assessment } \\
\text { In my role as a teacher, I feel that I am constantly developing more confidence in } \\
\text { my teaching career and that I become safer in different classroom situations. At } \\
\text { the same time, I feel that there is always a progression in the work we do in the } \\
\text { teacher team. Previously, we have worked with assessment for learning, and now } \\
\text { we are working with constructive alignment. In these common meetings, we learn } \\
\text { from each other and test new methods in the classroom. This means that, the more } \\
\text { knowledge I get, the more I am active in the teacher team's discussions. }\end{array}$ & $\begin{array}{l}\text { Finally, the student is relating } \\
\text { (level 1) to the difference between } \\
\text { resources. } \\
\text { Workplace-based learning needs } \\
\text { to be developed, but there is a } \\
\text { lack of support from school. The } \\
\text { further conclusion is relating } \\
\text { (level 1) to the relationship } \\
\text { between personal and collegial } \\
\text { learning about assessment } \\
\text { for learning and constructive } \\
\text { alignment. This promotes the } \\
\text { quality of the vocational program. } \\
\text { However, there is a lack of theory. }\end{array}$ \\
\hline
\end{tabular}

or within the students' own teaching position as informal teachers. These processes of reflection can help learners develop new ways of critical thinking through written and oral reflections and conclusions of self-assessment (Bain et al., 2002), supported by a MLH. The MLH with different folders per semester (see figure 1) supported reflection-on-action after the element of knowing-in- 
Table 4. Student 3 is from a restaurant and food program and has worked as a head cook for many years

\begin{tabular}{l} 
From the Log Journal \\
\hline Critical incident semester 1 \\
After the first semester, I realize that there is so much more than just learning. I \\
need to get a deeper insight into different methods and theories of learning to fully \\
understand what I can do. My lesson planning feels good, but I have to develop and \\
adapt my lessons also to the individual pupils I'm teaching, not only the whole class. \\
Conclusions of self-assessment \\
Theoretically, I want to understand why things are happening and how research would \\
be useful. Also to constantly update my subject-specific knowledge. The practical \\
part feels quite ok when I've used "hands-on learning" throughout my life. However, \\
I feel that I would like to observe theoretical lessons to learn even more how different \\
theories are combined, but also to get insight in how other teachers I work with behave \\
and handle learning according to different didactic methods.
\end{tabular}

\section{Critical incident semester 2}

My absolute first reflection on this semester is that I have so much left to learn. What I have focused on is to listen and take in more of everything that happens around me in classroom situations. I am interested in the theories of Socrates and Dewey, and I want to teach pupils through meaningful discussions and to learn while they are doing tasks. Learning shall come naturally by their curiosity, but catching and holding their interest is not easy.

\section{Conclusions of self-assessment}

I really feel that I am in need of learning to be able to concretize what I expect from the pupils and what I want them to achieve. My language use as a teacher needs also to be improved, I realize after reading the literature we had this semester, in using my vocational language. The absolute biggest and most important thing I reflected on was, after our tripartite conversation, I implemented the things I was criticized for and afterward had the best lesson ever. If the a-ha experiences will continue that way, this profession will be my best choice ever.

\section{Critical incident semester 3}

Reflections from this semester include, in particular, how much and how different I as a teacher must work to reach all pupils. It's not just to be a teacher and making use of clear and relevant material. I have been in many different meetings regarding a pupil and have worked out different ways to get this pupil to achieve the grade E [approved], as this is extremely important for his future (course literature). The responsibility of the pupil is negligible, according to course literature the pupils should take responsibility.

\section{Conclusions of self-assessment}

During the tripartite conversation, I primarily assume that I will try to use the knowledge I have, but spend more time to understand the connection between the theories we are reading. I think more about different difficulties pupils can have and how they can turn out. I have to adapt my teaching in different ways.

\section{Critical incident semester 4}

When I now summarize the practice I have done over two years, the first thing I think about is the nervousness I had when I started VTEP. That I would go from novice to professional felt so incredibly far away. Creating a good relationship to the pupils, and to the teacher team, and not least to myself in my new role as vocational teacher are incredibly important (course literature). Developing strategies to reach out to all pupils in the way they want to be treated and to go from pure facts to understanding what they really want to learn, is one of the keys for success (course literature).

\section{Conclusions of self-assessment}

The fact that I, as a student teacher, am taking care of thoughts, education, and research in the field of education, I consider is a survival instinct. Teaching goes in circles, and what I think I need additional knowledge in is primarily to use assessment in a formative way for pupils' learning (course literature). As a teacher, I shall provide feedback in a way that the pupils understand, so they can achieve their full potential (course literature). I must also critically review what I do, for example, through auscultations to reach further development as teacher (course literature).
Application of the 5Rs Scale

In these sentences, the student is reporting (level 1) about the need of insights into different methods and theories to fully understand them and to develop individualized teaching. The further conclusion is relating (level 1) on the relationship between vocational knowledge and theories and how they can be integrated into teaching, as well as how colleagues are teaching. However, there is a lack of theories or examples.

Here the student is relating (level 2) learning in classroom situations and theoretical

understandings to Socrates' idea of meaningful discussions and Dewey's idea of learning by doing, albeit in a limited way.

The further conclusion is responding (level 2) to the meaning of the use of vocational language in practice after reading the literature. Additionally, the student responds to the importance of a tripartite conversation to get feedback on what can be developed and in what way.

Here the student is relating (level 2) to working in different ways to encourage pupils to take responsibility for their studies and achieve approved grades, with superficial connections to some literature. The further conclusion is responding (level 2) to the importance of the tripartite conversation with the university teacher and the supervisor at school for support in teaching.

Finally, the student is reasoning (level 3) about two insights, first the development from novice to professional connected to the importance of relationship to all pupils, the teacher team, and oneself based on literature, and second the didactic strategies as keys for success. The further conclusion is a reconstruction (level 4) with new teaching understandings and a personal approach to use formative assessment for learning, as well as a critical review of teaching theory for further development as teacher. 
action, both mobile and blended, which occurs while an action is being undertaken through written and oral reflections and self-assessment (Schön, 1987). The assistance of professionals as coaches with written and oral material for reciprocal reflection between the student and the coach is needed about different problem solving (Townsend, 2010). This is also one means for distinguishing between the learners' roles as 'experts' in their vocational profession from their status as 'novices' in the teacher profession (Grossman, 2009).

More specifically, the results answer the first and third research questions focused on what characterizes student teachers' reflection capabilities and which situations, incidents, or issues in their written log journals are addressed and self-assessed. First, the excerpts show contentbased reflections, where experiences are measured against practical and theoretical knowledge. Through written log journals with self-assessed conclusions and followed up with participating in mobile online webinars F2F discussions, the students were able to reflect on what way they learned from different situations, incidents, or issues (Grossman, 2009). Highlighted are the areas of professional didactic theories, pedagogical leadership, and formative assessment. Essentially, the process for gathering certain important facts concerning a clear situation, incident, or issue and afterwards critically reflecting and self-assessing them (Flanagan, 1954). Furthermore, the MLH provides broader conditions for both mobile and blended learning during the four school-based vocational training courses. The students could learn anywhere and at any time, and easily switch learning contexts to another or across various dimensions of scenarios (Amhag, 2016, 2017; Lan \& Lin, 2016; Marin et al., 2016; Wong, et al., 2015). However, it is crucial to approach these processes with explicit scaffolding by teachers. In the present case, scaffolding occurred through the tripartite conversation that encouraged the students to focus on theoretical and practical evidence in a well-communicated text, as well as to determine if something has real value to put into practice in a particular context (Bain et al., 2002; Dewey, 1997; Hatton \& Smith, 1995; Ryan, 2013).

Second, the excerpts show that students progressed to 'higher order thinking' levels of reflection when different strategies and experiences of enthusiasm allowed them to distinguish between "novice" in teaching and "expert" in the profession (Grossman, 2009). Through careful and critical reflection on direct experiences, conclusions of self-assessment can be formulated (Dewey, 1938/1997). However, both separate and connected knowing are important to develop reflective thinking, both at an individual and a group level; students need different kinds of mobile and blended support to improve their reflective thinking (Enochsson, 2017). Students search for help from teachers and fellow students, as well as needing challenging encouragement to develop this reflective capacity to connect practical and theoretical knowledge (Ryan, 2013). Awareness of the value of the written contributions and experience exchanges in the log journals emerged during the mobile discussions online F2F (Meyer, 2003; Richardson \& Ice, 2010; Schellens \& Valcke, 2005; Wegerif, 2007).

Third, the excerpts show that "self-authorship" reflection helps students separate thoughts and feelings from empathetic input (e.g., the teacher mission, relationships or pupils' responsibility, and motivation for learning). Through self-authorship, students generate deeper reflection and awareness of that there is often more than one possible interpretation of different experiences (Grossman, 2009).

Fourth, the excerpts demonstrate transformative reflection, which is a deeper level of reflection, developed by involving and evaluating awareness of critical thinking and learning, the value of careful perceiving, and reflective acting, supported by a mobile learning hub. In this transformative reflection, students learn through increased theoretical and practical ability and critical higher-order thinking, and they become less dependent on false assumptions and statements (Archer, 2010; Grossman, 2009; Kuhn, 2016). However, the pedagogical practice does not translate knowledge of itself; without developing students' intellectual stance in dealing with critical issues and practices, and where the student has the authority to initiate changes (Giroux, 2010). 
In summary, the results highlight the process of reflection on experiences in relation to self, others, and contextual conditions in progression in vocational training courses in higher distance education, supported by mobile and blended tools; and importantly, students' knowledge progression to plan and anticipate future experiences for personal and professional learning (Dewey 1938/1997; Ryan, 2013).

\section{ACKNOWLEDGMENT}

Many thanks to Nordplus Horizontal (www.nordplusonline.org), for the project support, NPHZ2014/10182, for the study, and to Ellen Shuman, from Edanz Group (www.edanzediting.com/ac), for editing a draft of this manuscript. 


\section{REFERENCES}

Amhag, L. (2016a). Mobile technologies for student centered learning in a distance higher education program. I Janet Holland (Ed.). Wearable Technology and Mobile Innovations for Next-Generation Education, Ch. 10, pp. 184-199. IGI Global, http://www.igi-global.com/book/wearable-technology-mobile-innovations-next/142108

Amhag, L. (2017). Mobile-Assisted Seamless Learning Activities in Higher Distance Education. International Journal of Higher Education, 6(3). doi:10.5430/ijhe.v6n3p70

Archer, M. (2010). Routine, Reflexivity, and Realism. Sociological Theory, 28(3), 272-303. doi:10.1111/j.14679558.2010.01375.x

Ashwin, P., Boud, D., Coate, K., \& Hallett, F. (2015). Reflective Teaching in Higher Education. New York: Bloomsbury Academic.

Bach, S., Haynes, P., \& Lewis Smith, J. (2007). Online Learning and Teaching in Higher Education. Maidenhead, Berkshire, England: McGraw-Hill Education.

Bain, J.D., Ballantyne R., Mills, C. \& Lester, N.C. (2002). Reflecting on practice: Student teachers' perspectives. Flaxton: Post Pressed.

Boud, D. (1999). online 2007). Avoiding the traps: Seeking good practice in the use of self-assessment and reflection in professional courses. Social Work Education, 18(2), 121-132. doi:10.1080/02615479911220131

Chan, T.-W., Roschelle, J., Hsi, S., Kinshuk, , Sharples, M., Brown, , \& Hoppe, U. et al. (2006). One-to-one technology-enhanced learning: An opportunity for global research collaboration. Research and Practice in Technology-Enhanced Learning, 1(1), 3-29. doi:10.1142/S1793206806000032

Clinchy, B. M. V. (1996). Connected and separate knowing. In N. R. Goldberger, J. M. Tarule, B. M. Clinchy, \& M. F. Belenky (Eds.), Knowledge, difference and power: Essays inspired by Women's ways of knowing (pp. 205-247). New York: Basic Books.

De Wever, B., Van Keer, H., Schellens, T., \& Valcke, M. (2009). Structuring asynchronous discussion groups: The impact of role assignment and self-assessment on students' levels of knowledge construction through social negotiation. Journal of Computer Assisted Learning, 25(2), 177-188. doi:10.1111/j.1365-2729.2008.00292.x

Dewey, J. (1997). Experience and Education. New York: Touchstone. (Original work published 1938)

Dickhut, J. E. (2003). A brief review of creativity. Personality Research. Retrieved from www.personalityresearch. org/papers/dickhut.html

Dochy, F., Segers, M., \& John Sluijsmans, D. (1999). The use of self-, peer- and co-assessment in higher education: A review. Studies in Higher Education, 24(3), 331-350. doi:10.1080/03075079912331379935

Enochsson, A. B. (2017). Reflective discussions in teacher training: A comparison between online and offline discussions of course literature in a class of pre-service teachers. Education and Information Technologies. doi: $10.1007 / \mathrm{s} 10639-017-9602-5$

Flanagan, J. (1954). The critical incident technique. Psychological Bulletin, 51(4), 327-358. doi:10.1037/ h0061470 PMID:13177800

Giroux, H. (2010). Teachers as transformative intellectuals. In Kaleidoscope: Contemporary and classic readings in education (pp. 35-40).

Grossman, R. (2009). Structures for Facilitating Student Reflection. College Teaching, 57(1), 15-22. doi:10.3200/ CTCH.57.1.15-22

Hatton, N., \& Smith, D. (1995). Reflection in teacher education: Towards definition and implementation. Teaching and Teacher Education, 11(1), 33-49. doi:10.1016/0742-051X(94)00012-U

Hwang, G.-J., Lai, C.-L., \& Wang, S.-Y. (2015). Seamless flipped learning: A mobile technology enhanced flipped classroom with effective learning strategies. Journal of Computer Education, 2(4), 449-473. doi:10.1007/s40692-015-0043-0

Kegan, R. (1994). In over our heads: The mental demands of modern life. Harvard University Press. 
Kostons, D., van Gog, T., \& Paas, F. (2010). Self-assessment and task selection in learner-controlled instruction: Differences between effective and ineffective learners. Computers \& Education, 54(4), 932-940. doi:10.1016/j.compedu.2009.09.025

Kuh, G. D. (1996). Guiding principles for creating seamless learning environments for undergraduates. College Student Development, 37(2), 135-148.

Kuhn, D. (1989). Children and adults as intuitive scientists. Psychological Review, 96(4), 674.

Kuhn, D. (2016). A Role for Reasoning in a Dialogic Approach to Critical Thinking. Topoi.

Lan, Y. J., \& Lin, Y. T. (2016). Mobile Seamless Technology Enhanced CSL Oral Communication. Journal of Educational Technology \& Society, 19(3), 335-350.

Marin, V. I., Jääskelä, P., Häkkinen, P., Juntunen, M., Rasku-Puttonen, H., \& Vesisenaho, M. (2016). Seamless Learning Environments in Higher Education with Mobile Devices and Examples. International Journal of Mobile and Blended Learning, 8(1), 51-68. doi:10.4018/IJMBL.2016010104

McIntosh, P. (2010). Action research and reflective practice. London: Routledge. doi:10.4324/9780203860113

Meyer, K. (2003). Face-to-face versus threaded discussions: The role of time and higher-order thinking. Journal of Asynchronous Learning Networks, 7(3), 55-65.

Pegrum, M., Oakley, G., \& Faulkner, R. (2013). Schools going mobile: A study of the adoption of mobile handheld technologies in Western Australian independent schools. Australasian Journal of Educational Technology, 29(1). doi:10.14742/ajet.64

Richardson, J. C., \& Ice, P. (2010). Investigating students' level of critical thinking across instructional strategies in online discussions. Internet and Higher Education, 13(1-2), 52-59. doi:10.1016/j.iheduc.2009.10.009

Ryan, M. (2013). The pedagogical balancing act: Teaching reflection in higher education. Teaching in Higher Education, 18(2), 144-155. doi:10.1080/13562517.2012.694104

Schellens, T., \& Valcke, M. (2005). Collaborative learning in asynchronous discussion groups: What about the impact on cognitive processing? Computers in Human Behavior, 21(6), 957-975. doi:10.1016/j.chb.2004.02.025

Schön, D. (1987). Educating the Reflective Practitioner. San Francisco, London: Jossey-Bass Publishers.

Shaheen, R. (2010). Creativity and Education. Creative Education, 1(3), 166-169. doi:10.4236/ce.2010.13026

Sumsion, J., \& Fleet, A. (1996). Reflection: Can we assess it? Should we assess it? Assessment \& Evaluation in Higher Education, 21(2), 121-130. doi:10.1080/0260293960210202

Wegerif, R. (2006). A dialogic understanding of the relationship between CSCL and teaching thinking skills. International Journal of Computer-Supported Collaborative Learning.

Wong, L.-H. (2013). Analysis of Students' After-School Mobile-Assisted Artifact Creation Processes in a Seamless Language Learning Environment. Journal of Educational Technology \& Society, 16(2), $198-211$. http://www.jstor.org/stable/jeductechsoci.16.2.198

Wong, L.-H., Chai, C. S., Aw, G. P., \& King, R. B. (2015). Enculturating seamless language learning through artefact creation and social interaction process. Interactive Learning Environments, 23(2), 130-157. doi:10.10 80/10494820.2015.1016534

Wong, L.-H., \& Looi, C.-K. (2011). What seams do be remove in mobile-assisted seamless learning? Computers \& Education, (57), 2364-238. doi:10.1016/j.compedu.2011.06.007

Lisbeth Amhag is Dr, Ph.D. and Asst. Professor in Education/Pedagogy at the Faculty of Education and Society, Malmö University, Sweden. Since 2002, Lisbeth is teaching students in Teacher Education 90 ECTS at distance and campus; is course leader and examiner/assessor at ground and advanced levels. Has published several national and international articles and conference papers about e-learning and formative assessment and is active in the further development of distance education and mobile learning. Lisbeth received Malmö University Teaching Award 2010 with students' motivation to be "competent, serious and challenging." Please address correspondence regarding this article to Lisbeth Amhag, Faculty of Learning and Society, 20506 Malm€o University, Sweden. E-mail: lisbeth.amhag@mau.se. 